\title{
Electrolyte Economy and Its Hormonal Regulation in Congenital Chloride Diarrhea
}

\author{
C. HOLMBERG ${ }^{(42)}$ \\ Children's Hospital, University of Helsinki, SF-00290 Helsinki 29, Finland
}

Summary

The economy of $\mathrm{Cl}^{-}, \mathrm{K}^{+}$, and $\mathrm{Mg}^{++}$, extracellular volume (ECV) and plasma volume, and the role of hyperreninemia and hyperaldosteronism were explored in 22 patients with congenital chloride diarrhea. Stool volume was in significant correlation with its $\mathrm{Cl}^{-}, \mathrm{Na}^{+}$and $\mathrm{K}^{+}$content, the correlation being significantly better with $\mathrm{Cl}^{-}$content than with the $\mathrm{Na}^{+}$content. Low fecal $\mathrm{Cl}^{-}$concentrations were seen in chronic hypochloremic contraction, but acute episodes did not cause reduction of fecal $\mathrm{Cl}^{-}$concentration from the basal level of 140-150 mmol/ liter. The adequate condition (defined as normal serum electrolyte concentrations and blood $\mathrm{pH}$, and presence of $\mathrm{Cl}^{-}$in urine) was associated with high total exchangeable $\mathrm{Cl}^{-}$and $\mathrm{ECV}$. This excess $\mathrm{Cl}^{-}$and $\mathrm{ECV}$ roughly equalled the high daily fecal amount of $\mathrm{Cl}^{-}$and volume. Reduced $\mathrm{ECV}$ was accompanied by high renin activities and hyperaldosteronism, but in the adequate condition these were normal. Hyperaldosteronism caused a decrease in urinary $\mathrm{Na}^{+} \cdot \mathrm{K}^{+}$ratio and, after the age of 2-6 months, in the fecal $\mathrm{Na}^{+}-\mathrm{K}^{+}$ratio. Total exchangeable $\mathrm{K}^{+}$was normal in the adequate condition. $\mathrm{No} \mathrm{Mg}^{++}$depletion was present, although the patients lack $\mathrm{Mg}^{++}$substitution. The adequate condition could be maintained with an oral supplement of $\mathrm{NaCl}, \mathrm{KCl}$ and water.

\section{Speculation}

Hyperreninemia, hyperaldosteronism, and hypokalemic alkalosis in congenital chloride diarrhea (CCD) are secondary to hypochloremic ECV contraction and can be completely corrected with adequate substitution. $\mathrm{Mg}^{++}$depletion does not play a part in CCD. The intestinal response to hyperaldosteronism appears later in the intestine than in the kidney in the newborn CCD patient and presumably also in the normal newborn.

Congenital chloride diarrhea is caused by an inborn error in the intestinal $\mathrm{Cl}^{-}$transport. Perfusion studies have shown that the active $\mathrm{Cl}^{-} / \mathrm{HCO}_{3}^{-}$exchange of the ileum and the colon is defective $(3,17,30,36)$. This results in osmotic diarrhea with high fecal $\mathrm{Cl}^{-}$concentration and acidity.

The characteristic state of CCD patients is hypochloremic, hypokalemic metabolic alkalosis, with high renin activity, hyperaldosteronism, and impaired renal function $(9,11,13,14,18$, 30 ). It has been suggested that $\mathrm{K}^{+}$depletion contributes to the intestinal absorption defect (11), and the renal pathology of $\mathrm{CCD}$ resembles that of experimental $\mathrm{Mg}^{++}$depletion (25).

As CCD is a "Finnish disease," it has been the object of a long term investigation at this hospital $(17-19,23,27-29,31)$. For further characterization of the fluid and electrolyte derangement in CCD the following aspects were investigated: the economy of $\mathrm{Cl}^{-}, \mathrm{K}^{+}$, and $\mathrm{Mg}^{++}, \mathrm{ECV}$ and plasma volume (PV), and the role of hyperreninemia and hyperaldosteronism.

\section{SUBJECTS}

Twenty-two patients, aged 0.5-14.5 years (18), were studied. Their early long term substitution was with a $0.15-0.3 \mathrm{M}$ water solution of $\mathrm{KCl}$ only, the dose $\left(45-204 \mathrm{mmol} / \mathrm{m}^{2} / 24 \mathrm{hr}\right.$ ) being adjusted to maintain normal serum electrolyte concentrations. Several episodes of acute dehydration had occurred lasting up to a week during the first years of life, but the subsequent clinical condition of the patients had been good. They passed a constantly $\mathrm{Cl}^{-}$-free urine and tended to be slightly alkalotic.

Five years ago the therapy was changed to a $0.15-0.3 \mathrm{M}$ $\mathrm{NaCl}+\mathrm{KCl}$ solution with the molar ratio of the salts individually varying from $3: 1$ to $1: 1$. The dose was $60-216 \mathrm{mmol} / \mathrm{m}^{2}$ daily and was adjusted to maintain chloriduria in addition to normal serum electrolyte concentrations and blood $\mathrm{pH}$. Such a state will be referred to as the adequate condition.

The recordings of low serum electrolyte concentrations and alkalosis in this study were obtained from observations during acute exacerbations of the diarrhea, due to respiratory and gastrointestinal infections, and from observations in our early patients.

\section{METHODS}

Serum electrolyte concentrations and blood $\mathrm{pH}$ were measured according to standard methods. Urinary and fecal electrolyte excretion was always measured from 24-hr collections.

For measurement of total exchangeable $\mathrm{Cl}^{-}\left(\mathrm{TECl}^{-}\right), 0.3$ $\mu \mathrm{Ci} / \mathrm{kg}$ of ${ }^{36} \mathrm{Cl}, \mathrm{NaCl}$ solution $\left(>3 \mathrm{mCi} / \mathrm{g} \mathrm{Cl}^{-}\right)$was injected intravenously with $5 \%$ glucose. Urines and stools were collected and after an equilibration time of $24 \mathrm{hr}$ a spot plasma sample was taken. The specific activity in plasma $\mathrm{Cl}^{-}$was measured and used in the calculations (37). Because biologic half-life of $\mathrm{Cl}^{-}$is short in $\mathrm{CCD}$, the radiation dose was minimal.

ECV was calculated as the "corrected $\mathrm{Cl}^{-}$space" (6) from the same ${ }^{36} \mathrm{Cl}^{-}$measurements. PV was measured with human serum [ ${ }^{125}$ I] albumin (34).

Plasma renin activity was measured with radioimmunoassay (12) from samples taken in the supine position between 8 and 9 AM after an 8-hr fast. Urinary aldosterone excretion was measured from 24-hr urine with radioimmunoassay (1).

For measurement of total exchangeable $\mathrm{K}^{+}$(TEP) $3.5 \mu \mathrm{Ci}$ / $\mathrm{kg}\left[{ }^{42} \mathrm{~K}\right] \mathrm{KCl}$ solution $\left(300 \mu \mathrm{Ci} / \mathrm{g} \mathrm{K} \mathrm{K}^{+}\right)$in $5 \%$ glucose was injected intravenously. After an equilibration time of $24 \mathrm{hr}$, during which urines and stools were collected, a spot urine sample was taken. The specific activity in urine $\mathrm{K}^{+}$was measured and used in the calculations (7).

Serum and erythrocyte $\mathrm{Mg}^{++}$were measured according to standard methods (38). Muscle biopsies were taken according to the method of Bergström (2). Muscle $\mathrm{Mg}^{++}$content was determined with neutron activation analysis (39), and expressed in $\mathrm{mEq} / 100 \mathrm{~g}$ fat-free solids (FFS). For study of $\mathrm{Mg}^{++}$economy, Thoren's test was employed (35). 


\section{RESULTS}

\section{CHLORIDE ECONOMY}

The daily stool volume correlated with its $\mathrm{Cl}^{-}, \mathrm{Na}^{+}$, and $\mathrm{K}^{+}$ content $\left(r=0.89\right.$ for $\mathrm{Cl}^{-}, 0.82$ for $\mathrm{Na}^{+}$, and 0.66 for $\mathrm{K}^{+}, n=$ 113). This is to be expected because water is known to follow passively the movement of solutes in the intestine $(8)$. When the serum electrolyte concentrations were normal the fecal $\mathrm{Cl}^{-}$ concentration was usually $140-150 \mathrm{mmol} / \mathrm{liter}$. The correlation of volume was significantly better with the $\mathrm{Cl}^{-}$content than with the $\mathrm{Na}^{+}$content, which is also to be expected as the primary disturbance is one of active $\mathrm{Cl}^{-}$transport.

The fecal $\mathrm{Cl}^{-}$content showed a correlation with the serum $\mathrm{Cl}^{-}$concentration $(r=0.42, n=102)$, Figure 1 . Low fecal $\mathrm{Cl}^{-}$ concentrations were seen in patients who had been without substitution or on a small substitution dose for a long time and were hypochloremic. An extreme example was patient $J H$ who, after a trial of substitution with $\mathrm{K}^{+}$-lactate, had a fecal $\mathrm{Cl}^{-}$ concentration of only $40 \mathrm{mmol} / \mathrm{liter}$ (Table 2). His clinical condition was, however, miserable. Acute episodes of hypochloremia did not cause any reduction in fecal $\mathrm{Cl}^{-}$concentration (Fig. 2).

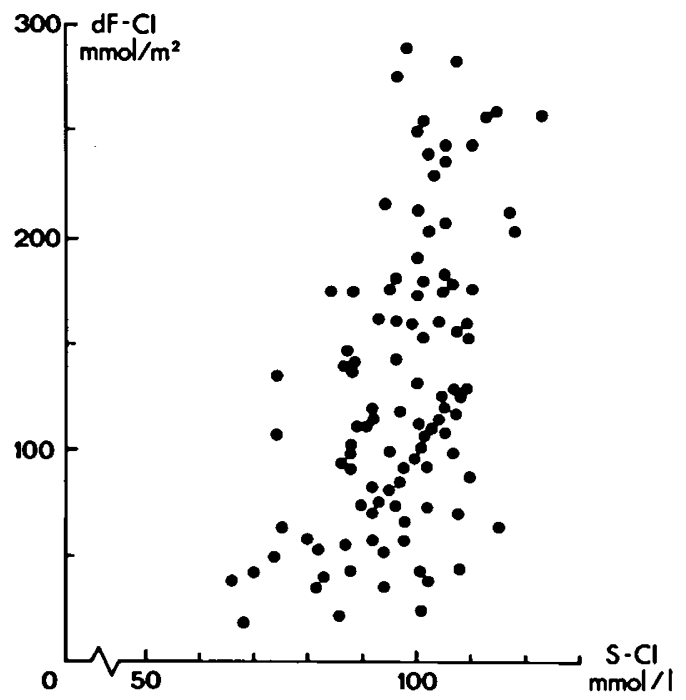

Fig. 1. Relationship of the amount of $\mathrm{Cl}^{-}$in 24-hr stool $(\mathrm{dF}-\mathrm{Cl})$ and the serum $\mathrm{Cl}^{-}(\mathrm{S}-\mathrm{Cl})$ concentration in patients with $\mathrm{CCD}$.

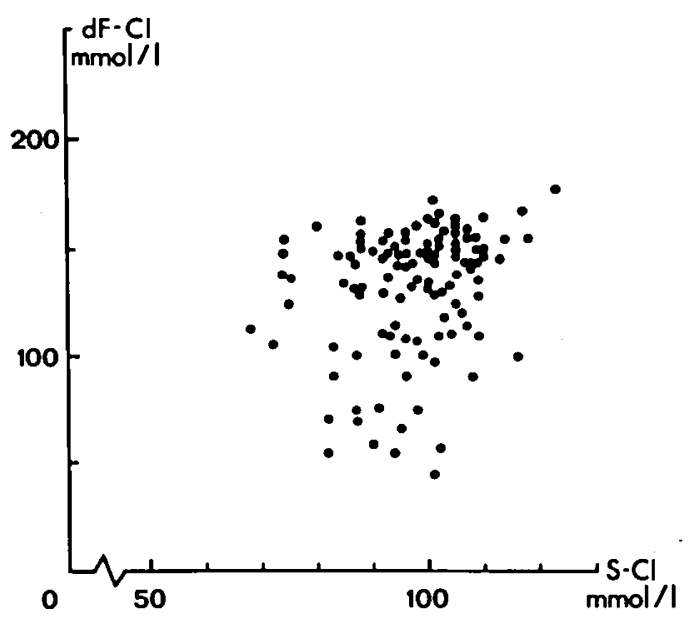

Fig. 2. Relationship of the concentration of $\mathrm{Cl}^{-}$in 24-hr stool ( $d F$ $\mathrm{Cl})$ and the serum $\mathrm{Cl}^{-}(\mathrm{S}-\mathrm{Cl})$ concentration in patients with CCD.

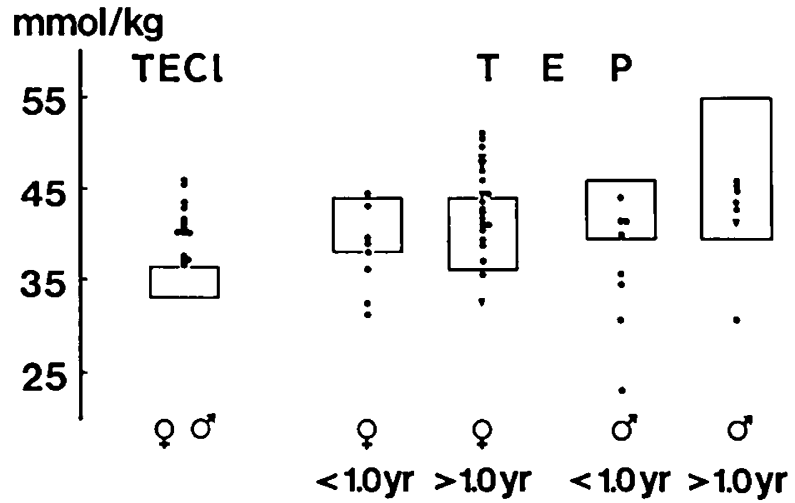

Fig. 3. TECl and TEP in patients with CCD. $\bullet: \mathrm{NaCl}+\mathrm{KCl}$ substitution; $\mathbf{\nabla}: \mathrm{KCl}$ substitution.

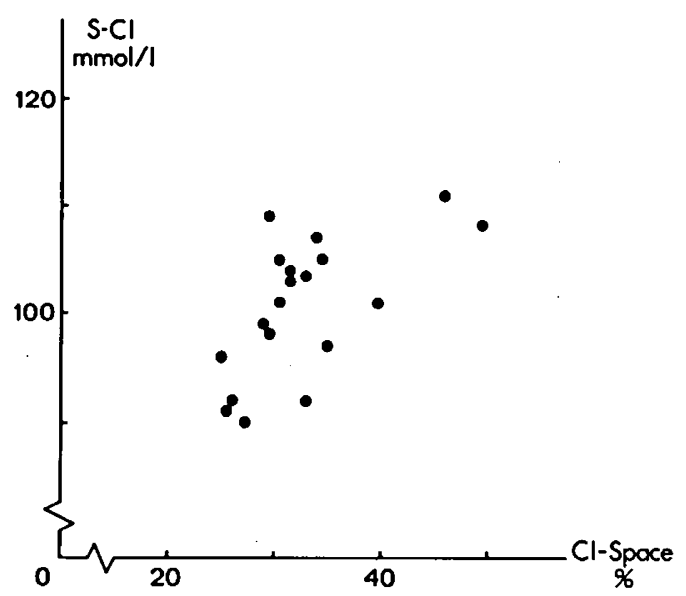

Fig. 4. Relationship of serum $\mathrm{Cl}^{-}(S-C l)$ concentration and ECV measured as the "corrected $\mathrm{Cl}^{-}$space" (Cl-Space) in patients with CCD.

The mean $\mathrm{TECl}^{-}$, measured in four patients $(23-33 \mathrm{~kg})$, was $30.7 \mathrm{mmol} / \mathrm{kg}$ (range $28.1-33.8 \mathrm{mmol} / \mathrm{kg}$ ) during hypochloremia. In 14 patients $(10-33 \mathrm{~kg})$ in the adequate condition it was $40 \mathrm{mmol} / \mathrm{kg}$ (Fig. 3). This is high compared with the $34.6 \pm$ $1.6 \mathrm{mmol} / \mathrm{kg}$ (mean $\pm \mathrm{SD}$ ) predicted for their weight according to the calculations of Cheek and Graystone (5). In two 1month-old infants $\mathrm{TECl}^{-}$was even higher, 61.0 and $71.0 \mathrm{mmol} /$ $\mathrm{kg}$ (mean normal 50.7 and $45.6 \mathrm{mmol} / \mathrm{kg}$, respectively).

\section{ECV AND PV, RENIN AND ALDOSTERONE}

ECV was also high in these patients. For six patients who weighed more than $20 \mathrm{~kg}$ the mean "excess ECV" (actual ECV less the mean ECV calculated for body weight) was 1.1 liter. This roughly equalled their daily fecal volume. In the abovementioned two infants the ECV was $46.1 \%$ and $49.5 \%$, respectively (mean normal $30 \%$ ). A decrease in serum $\mathrm{Cl}^{-}$concentration was constantly accompanied by a contraction of ECV (Fig. 4). Urinary excretion of $\mathrm{Cl}^{-}$always ceased when serum $\mathrm{Cl}^{-}$ concentration fell below $95 \mathrm{mmol} / \mathrm{liter}$ (18). Achloriduria is thus an indicator of hypovolemia.

PV was measured in seven patients together with.ECV and plasma renin activity (Table 1 ). PV was mostly normal. A subnormal recording in patient $A S$ was associated with "normal" $\mathrm{ECV}$, achloriduria, and elevated renin activity. PV recordings at the lower normal range ( $M K$ and $P I$ ) were accompanied by a slight rise in renin activity and sparse chloriduria. Normal recordings were accompanied by high ECV, chloriduria, and normal to "high normal" renin activities. 
Table 1. Indices of ECV in seven $C C D$ patients

\begin{tabular}{|c|c|c|c|c|c|c|}
\hline Subjects & $\begin{array}{l}\text { Wt, } \\
\mathrm{kg}\end{array}$ & $\begin{array}{l}\text { Urinary } \mathrm{Cl}^{-} \text {, } \\
\mathrm{mmol} / 24 \mathrm{hr}\end{array}$ & $\begin{array}{l}\mathrm{PV}, \\
\mathrm{ml} / \mathrm{kg}\end{array}$ & $\begin{array}{c}\mathrm{ECV}, \\
\%\end{array}$ & $\begin{array}{c}\text { Serum } \mathrm{Cl}^{-} \text {, } \\
\text { mmol/liter }\end{array}$ & $\begin{array}{c}\text { Plasma renin activ- } \\
\text { ity, } \\
\mu \mathrm{g} / \mathrm{l} / \mathrm{hr}\end{array}$ \\
\hline$A S$ & 25 & 0.0 & 28.7 & 29.0 & 96 & 4.7 \\
\hline$M K$ & 33 & 3.0 & 38.5 & 25.0 & 96 & 6.1 \\
\hline$P I$ & 16 & 23.8 & 36.1 & 31.6 & 103 & 4.8 \\
\hline$R K o$ & 33 & 14.5 & 40.6 & 30.3 & 105 & 1.7 \\
\hline$M V$ & 23 & 34.8 & 48.4 & 29.3 & 109 & 1.6 \\
\hline$L I$ & 20 & 85.4 & 40.7 & 30.5 & 101 & 3.1 \\
\hline$M H$ & 17 & 84.2 & 56.5 & 32.3 & 110 & 3.0 \\
\hline Normal values & & & $38-48$ & 25.0 & $93-113$ & $0.9-2.0$ \\
\hline
\end{tabular}

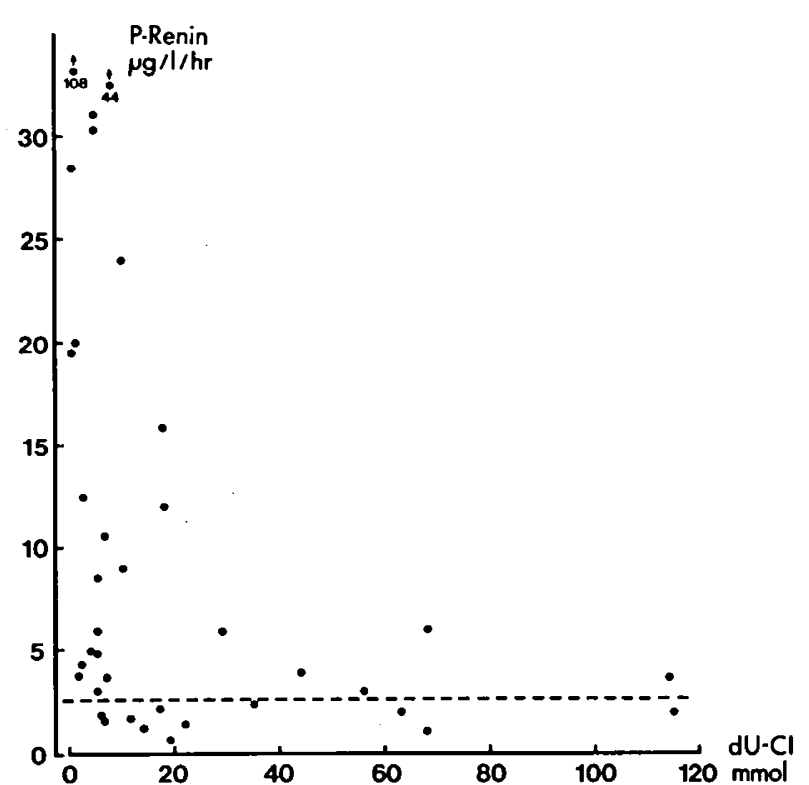

Fig. 5. Relationship of plasma renin (P-Renin) activity and the excretion of $\mathrm{Cl}^{-}$in 24-hr urine $(d U-C l)$ in patients with CCD.

As chloriduria is an indicator of the volemia in CCD, plasma renin activity was plotted against 24-hr urinary $\mathrm{Cl}^{-}$excretion (Fig. 5). With substantial chloriduria plasma renin activities were normal, whereas low or lacking chloriduria, that is reduced $\mathrm{ECV}$, was accompanied by high renin activities. When urinary 24-hr aldosterone excretion was plotted against the chloriduria the same pattern was seen (Fig. 6). Hyperaldosteronism was seen only when chloriduria was low or lacking.

\section{ALDOSTERONE EFFECT}

Hyperaldosteronism was accompanied by a decrease in urinary $\mathrm{Na}^{+}-\mathrm{K}^{+}$ratio indicating a normal renal response to aldosterone (Fig. 7). Normally, the distal intestine responds similarly to aldosterone (32). To investigate whether this occurs in the CCD patients, a correlation between the fecal $\mathrm{Na}^{+}-\mathrm{K}^{+}$ratio and the urinary $\mathrm{Na}^{+}-\mathrm{K}^{+}$ratio was sought. No such correlation was found in children below 6 months of age $(r=-0.06, n=32)$, but a clear correlation was present in the older children $(r=$ $0.37, P<0.01$ ). Thus an intestinal response to hyperaldosteronism, a decrease in the fecal $\mathrm{Na}^{+}-\mathrm{K}^{+}$ratio, was recorded, but only after the age of 6 months. The young infants did have hyperaldosteronism: urinary aldosterone excretions up to 59 $\mu \mathrm{g} / \mathrm{m}^{2} / 24 \mathrm{hr}$ were recorded. Lack of the intestinal response during the first months suggest that it matures later than the renal response.

Urinary and fecal $\mathrm{Na}^{+}-\mathrm{K}^{+}$ratios of patients in chronic dehydration are given in Table 2. Although already 6-9 months old, two of these patients had a higher $\mathrm{Na}^{+}-\mathrm{K}^{+}$ratio in the stools

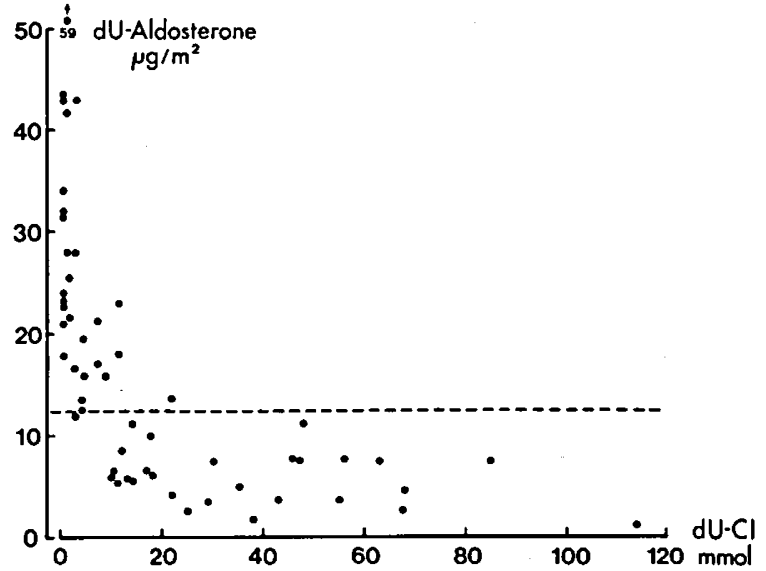

Fig. 6. Relationship of daily urinary aldosterone (dU-Aldosterone) excretion and the excretion of $\mathrm{Cl}^{-}$in $24-\mathrm{hr}$ urine $(d U-C l)$ in patients with CCD.

than in the urine. Three others, aged 9-30 months, had similar ratios in urine and stools. On the other hand, $J H$ had a low fecal ratio at the age of 2 months. This might reflect an exceptionally early maturation of the intestinal response or a very high aldosterone activity. His aldosterone excretion was high, $55 \mu \mathrm{g} / \mathrm{m}^{2} / 24 \mathrm{hr}$.

\section{POTASSIUM ECONOMY}

TEP was measured on 39 occasions in patients who were in "the adequate condition." TEP was normal in all children, who were older than 1 year, whether substituted with $\mathrm{KCl}$ or $\mathrm{NaCl}$ $+\mathrm{KCl}$ (Fig. 3). In the younger infants some subnormal values were recorded, although their serum $\mathrm{K}^{+}$concentrations were normal. The lowest TEP value recorded was in patient $J K$ who had been on a $0.9 \% \mathrm{NaCl}-0.2 \% \mathrm{KCl}$ solution until the age of 6 months because he showed a tendency to hyponatremia and hyperkalemia when newborn on our usual $0.7 \% \mathrm{NaCl}-0.3 \%$ $\mathrm{KCl}$ solution. When switched back to the latter solution his TEP became normal. The second lowest value in the same group was of patient $H P$, who was slightly alkalotic and without chloriduria. As his dose was increased TEP normalized.

$$
\mathrm{Mg}^{++} \text {ECONOMY }
$$

A total of 22 determinations of serum $\mathrm{Mg}^{++}$concentration was obtained from 13 patients. The levels ranged from $0.73-$ $1.06 \mathrm{mmol} / \mathrm{liter}$ (normal range $0.7-1.0 \mathrm{mmol} / \mathrm{liter}$ ), with a mean of $0.88 \mathrm{mmol} / \mathrm{liter}$. Erythrocyte $\mathrm{Mg}^{++}$concentration, determined 22 times from 11 patients, was 2.1-3.09 mmol/liter (normal range $2.43-2.85 \mathrm{mmol} / \mathrm{liter}$ ); the mean was $2.52 \mathrm{mmol} /$ liter. Of $0.5 \mathrm{mEq} \mathrm{Mg}{ }^{++} / \mathrm{kg}$ infused intravenously into eight patients, the mean of $70 \%$ was excreted in urine in $24 \mathrm{hr}$. Only 
two patients excreted less than $60 \%$ (40 and $56 \%$ ). The retention of more than $60 \%$ of the dose is considered to be a clear sign of $\mathrm{Mg}^{++}$depletion (16).

Muscle biopsies were taken from seven patients (including the two with less than $60 \%$ excretion) and two healthy control subjects, a 7.4-year-old girl and an adult male. The control subjects had muscle $\mathrm{Mg}^{++}$concentrations of 6.6 and $8.6 \mathrm{mEq} /$ $100 \mathrm{~g}$ FFS, respectively, both within the normal range $(10,26)$. The patients' values ranged from 6.6-10.6, mean $8.8 \mathrm{mEq} / 100$ $\mathrm{g}$ FFS. Because no low values were recorded, it is concluded that $\mathrm{CCD}$ does not cause $\mathrm{Mg}^{++}$depletion.

\section{DISCUSSION}

The adequate condition was accompanied by high $\mathrm{TECl}^{-}$and ECV in our patients. This seems to be a feature of the optimal state of CCD patients. The "excess" $\mathrm{Cl}^{-}$and EC fluid obviously is made up of the large intestinal content of $\mathrm{Cl}^{-}$and water in this disease. In agreement with this is our observation that the excess $\mathrm{Cl}^{-}$and $\mathrm{EC}$ fluid in the older patients was of the same magnitude as their daily fecal $\mathrm{Cl}^{-}$and volume. The $\mathrm{TECl}^{-}$and ECV were proportionately even larger in our infants, and so were their daily stool volumes (about $200 \mathrm{ml}$ for their weight of $2000 \mathrm{~g}$ in contrast to $1100 \mathrm{ml}$ for $30 \mathrm{~kg}$ ). Normal TECl${ }^{-}$and ECV have previously been recorded in CCD patients $(20,24$, 30 ), but these were usually associated with achloriduria and/or high hormonal activities, and thus, presumably with decreased real ECV.

It is clearly shown by the present investigation that the high renin activities and hyperaldosteronism appear only in ECV contraction. Achloriduria, which was formerly regarded as an inevitable feature of $C C D$, is also a result of the contraction. With proper substitution normal ECV and PV can be maintained, and this adequate condition is associated with normal plasma renin activity, normal urinary aldosterone excretion,

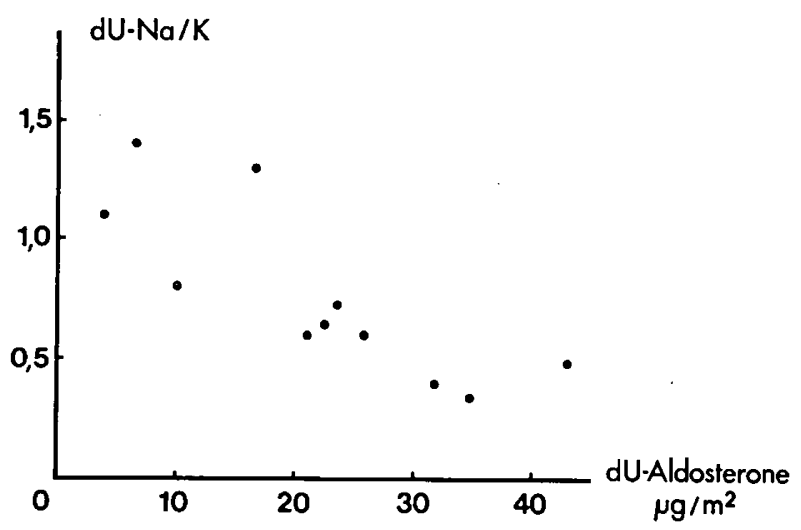

Fig. 7. Relationship of the $\mathrm{Na}^{+}-\mathrm{K}^{+}$ratio in 24-hr urine $(d U-\mathrm{Na} / \mathrm{K})$ and the daily urinary aldosterone ( $d U$-Aldosterone) excretion in patient $S A$. and chloriduria. Chloriduria is a convenient indicator of the adequacy of the therapy.

In the newborn normal aldosterone production was recorded (18) with the normal renal response seen as reversal of the urinary $\mathrm{Na}^{+}-\mathrm{K}^{+}$ratio. The fecal $\mathrm{Na}^{+}-\mathrm{K}^{+}$ratio did not change in the first months of life, but later a clear decrease was documented. Probably because of lateness $(1)$ of intestinal response to aldosterone resulting in enhanced $\mathrm{Na}^{+}$absorption and (2) of the appearance (secretion?) in the intestine of $\mathrm{NH}_{3}$ which binds the $\mathrm{H}^{+}$secreted in exchange for $\mathrm{Na}^{+}(18)$, "the typical stool composition of CCD" with a $\mathrm{Cl}^{-}$concentration exceeding the sum of $\mathrm{Na}^{+}$and $\mathrm{K}^{+}$appears only after the first months of life. With insufficient substitution the newborn developed a hypotonic contraction, whereas the older children maintained normal $\mathrm{Na}^{+}$concentration (18), but at the cost of renal (and intestinal) $\mathrm{K}^{+}$loss and alkalosis. This is also in agreement with the slow maturation of aldosterone response.

Hypokalemia has been a very common finding in CCD. An impairment of $\mathrm{K}^{+}$transport has even been proposed for the basic defect $(21)$, and many authors have underlined that $\mathrm{K}^{+}$ depletion may further reduce a primarily disturbed $\mathrm{Cl}^{-}$absorption $(11,20)$. Thus, substitution with $\mathrm{KCl}$ alone was the rule in the first cases described. Our perfusion studies of the colon in three $\mathrm{CCD}$ patients revealed a larger than normal $\mathrm{K}^{+}$loss, and this was explained as secretion of $\mathrm{K}^{+}$along with $\mathrm{H}^{+}$in exchange for $\mathrm{Na}^{+}(17)$. The present results show that TEP was normal in most of our patients on both $\mathrm{KCl}$ and $\mathrm{NaCl}+\mathrm{KCl}$ substitution. Low TEP values were recorded among the younger children during inadequate substitution; the values normalized on increasing the daily $\mathrm{K}^{+}$dose. Normal TEP can thus be maintained with a substitution that compensates for the fecal loss and inhibits hyperaldosteronism.

The hypokalemic alkalosis of inadequately substituted patients is the result of three factors. (1) The hypochloremia caused by the fecal loss of $\mathrm{Cl}^{-}$results in reduced delivery of $\mathrm{Cl}^{-}$ to the renal tubules. Thus, more $\mathrm{HCO}_{3}^{-}$is absorbed with $\mathrm{Na}^{+}$, presumably both in the proximal and distal tubules $\left(\mathrm{HCO}_{3}^{-}\right.$ absorption and $\mathrm{H}^{+}$secretion). (2) The contraction of ECV increases the maximal $\mathrm{HCO}_{3}^{-}$reabsorption (33). (3) Hyperaldosteronism enhances renal (22) and intestinal (32) $\mathrm{K}^{+}$loss, and $\mathrm{K}^{+}$depletion further increases the alkalosis (33). To correct the derangement, the hypochloremia, the contraction, and the $\mathrm{K}^{+}$depletion must all be treated.

An $\mathrm{Mg}^{++}$depletion is known to accompany chronic diarrhea $(16,35)$. It has also been reported in one CCD patient $(15)$, and low urinary excretion of $\mathrm{Mg}^{++}$was recorded in our patients (18). Furthermore, as the renal lesion in CCD resembled the one seen in experimental $\mathrm{Mg}^{++}$depletion, we had to consider $\mathrm{Mg}^{++}$depletion as a feature complicating $\mathrm{CCD}$. However, according to the present findings, $\mathrm{Mg}^{++}$economy is normal in $\mathrm{CCD}$ patients on adequate $\mathrm{NaCl}-\mathrm{KCl}$ substitution, and magnesium depletion is an unlikely etiologic factor of the renal lesion.

The pathophysiology of CCD seems to be largely established. The primary disturbance is an inborn error of metabolism which results in a defect of the active $\mathrm{Cl}^{-} / \mathrm{HCO}_{3}^{-}$exchange in the

Table 2. Serum electrolyte concentrations, base excess (BE), and 24- $\mathrm{hr}$ urinary and fecal excretion of $\mathrm{Na}^{+}, \mathrm{K}^{+}$, and $\mathrm{Cl}^{-}$and $\mathrm{Na}^{+}-\mathrm{K}^{+}$ ratio in six CCD patients after chronic contraction and hypoelectrolytemia of several weeks' duration

\begin{tabular}{|c|c|c|c|c|c|c|c|c|}
\hline \multirow[b]{2}{*}{ Subjects } & \multirow{2}{*}{$\begin{array}{c}\text { Age, } \\
\text { mo }\end{array}$} & \multicolumn{4}{|c|}{ Serum (blood), mmol/liter } & \multirow{2}{*}{$\frac{\text { Urine, mmol }}{\mathrm{Na}^{+} / \mathrm{K}^{+}\left(\mathrm{Na}^{+} ; \mathrm{K}^{+} ; \mathrm{Cl}^{-}\right)}$} & \multirow{2}{*}{$\frac{\text { Feces, mmol }}{\mathrm{Na}^{+} / \mathrm{K}^{+}\left(\mathrm{Na}^{+} ; \mathrm{K}^{+} ; \mathrm{Cl}^{-}\right)}$} & \multirow{2}{*}{$\begin{array}{c}\text { Treatment, } \\
\mathrm{mmol} \mathrm{Cl} / / \mathrm{m}^{2} / 24 \mathrm{hr}\end{array}$} \\
\hline & & $\mathrm{Na}^{+}$ & $\mathrm{K}^{+}$ & $\mathrm{Cl}^{-}$ & $\mathrm{BE}$ & & & \\
\hline$J T(n=6)^{1}$ & 6 & 140 & 4.0 & 100 & +7.2 & $0.13(6.8 ; 39.1 ; 0.2)$ & $1.88(39.5 ; 21.2 ; 88)$ & 142 \\
\hline$A S(n=5)$ & 9 & 140 & 2.5 & 90 & +15 & $0.07(1.8 ; 26.2 ; 0.7)$ & $1.27(17.9 ; 14.5 ; 48)$ & 82 \\
\hline$R K o(n=4)$ & 9 & 135 & 2.5 & 85 & +15 & $0.02(0.4 ; 19.1 ; 0.2)$ & $0.05(8: 3 ; 14.7 ; 35)$ & 88 \\
\hline$R J(n=9)$ & 9 & 140 & 4.5 & 100 & +5.2 & $0.77(19.7 ; 26.1 ; 2.4)$ & $0.83(22.1 ; 26.8 ; 78)$ & \\
\hline$M K(n=5)$ & 30 & 135 & 4.5 & 115 & +2.3 & $0.01(0.2 ; 43.5 ; 0.4)$ & $0.26(15.8 ; 53.7 ; 88)$ & 216 \\
\hline$J H(n=6)$ & 2 & 120 & 2.5 & 70 & +10 & $0.05(0.0 ; 3.9 ; 0.0)$ & $0.49(4.9 ; 10.3 ; 6.4)$ & $\begin{array}{c}86 \\
\left(\mathrm{~K}^{+}-\text {lactate }\right)\end{array}$ \\
\hline
\end{tabular}

\footnotetext{
' Number of measurements used in calculations.
} 
ileum and the colon. The deficient absorption of $\mathrm{Cl}^{-}$results in osmotic diarrhea. With deficient $\mathrm{HCO}_{3}^{-}$secretion $\mathrm{H}^{+}$, which is secreted in exchange for $\mathrm{Na}^{+}$, accumulates in the intestinal contents and blocks further $\mathrm{Na}^{+}$absorption. If the intestinal electrolyte and water loss is not replaced, a hypochloremic ECV contraction develops, with high plasma renin activity and hyperaldosteronism. In the newborn with an immature response to aldosterone, the contraction is hypo-osmolal. If the infant survives, the renal $\mathrm{Na}^{+}$absorption and $\mathrm{K}^{+}$secretion are enhanced during the first weeks of life and normonatremia may recur spontaneously. Although urinary $\mathrm{Cl}^{-}$is completely absorbed, hypochloremia, ECV contraction, and hyperaldosteronism persist during normal salt intake. A hypokalemic metabolic alkalosis is maintained. Through an intestinal response to hyperaldosteronism the fecal $\mathrm{Na}^{+}-\mathrm{K}^{+}$ratio is reduced after the first months of life. When $\mathrm{NH}_{3}$ appears in the intestine and binds the $\mathrm{H}^{+}$secreted in exchange for $\mathrm{Na}^{+}$, the fecal $\mathrm{Cl}^{-}$ concentration will exceed the sum of $\mathrm{Na}^{+}$and $\mathrm{K}^{+}$. If adequate substitution is not instituted most patients will die in the first months of life but some will survive with retarded development (18).

Because the proximal small intestine is permeable to $\mathrm{Cl}^{-}$a normal state can be maintained with an oral replacement of the electrolytes and water lost in the stools. The dose has to be adjusted individually to maintain normal serum electrolyte concentrations, blood $\mathrm{pH}$, and normal ECV. Chloriduria is a convenient indicator of the normality of ECV. In this "normal" state $\mathrm{TECl}^{-}$and ECV, as regularly measured, are high. PV and renin activity, as well as aldosterone excretion, are normal. The diarrhea is thus maintained, but a completely normal development and social adjustment are possible (18).

\section{CONCLUSION}

The economy of $\mathrm{Cl}^{-}, \mathrm{K}^{+}$, and $\mathrm{Mg}^{++}, \mathrm{ECV}$ and $\mathrm{PV}$, and the role of hyperreninemia and hyperaldosteronism were studied in 22 patients with CCD. The hypokalemic metabolic alkalosis and the high hormone activities were shown to be the result of hypochloremic contraction caused by intestinal $\mathrm{Cl}^{-}$and water loss. An intestinal response to hyperaldosteronism was documented, but only after the first months of life. $\mathrm{Mg}^{++}$economy was normal. Normal serum electrolyte concentrations and blood $\mathrm{pH}$ as well as normal ECV, PV, and hormone activities could be maintained with an oral supplement of $\mathrm{NaCl}, \mathrm{KCl}$, and water. Chloriduria is a convenient indicator of the normality of $\mathrm{ECV}$, and thus of the adequacy of the $\mathrm{Cl}^{-}$substitution dose.

\section{REFERENCES AND NOTES}

1. Bayard, F., Baitins, I. Z., Kowarski, A., and Migeon, C. J.: Measurement of aldosterone secretion rate by radioimmunoassay. J. Clin. Endocrinol., 31: 507 (1970).

2. Bergström, J.: Muscle electrolytes in man. Scand. J. Clin. Lab. Invest., 14: (Suppl, 68) (1962).

3. Biberdorf, F. A., Gorden, P., and Fordtran, J. S.: Pathogenesis of congenital alkalosis with diarrhea. J. Clin. Invest., S1: 1958 (1972)

4. Chaptal, J., Jean, R., Dossa, D., Meylan, F., Morel, G., and Rieu, D.: Diarrhée chlorée congénitale: Étude clinique et biologique d'une observation de l'enfant. Ann. Pédiat., 16:326 (1967).

5. Cheek, D. B., and Graystone, J. E.: Intracellular and extracellular volume and exchangeable chloride in children. In: D. B. Cheek: Human Growth, p. 150 (Lea \& Febiger, Philadelphia, 1968).

6. Cheek, D. B., and Talbert, J. L.: Extracellular volume and body water in infants. In: D. B. Cheek: Human Growth, p. 117 (Lea \& Febiger, Philadelphia, 1968).

7. Corsa, L., Olney, J. M., Steenburg, R. W., Ball, M. R., and Moore, F. D.: The measurement of exchangeable potassium in man by isotope dilution. $J$. Clin. Invest., 29: 1280 (1950).

8. Curran, P. F.: Water absorption from the intestine. Amer. J. Clin. Nutr., 21: 781 (1968).
9. Darrow, D. C.: Congenital alkalosis with diarrhea. J. Pediat., 26: 519 (1945).

10. Elliot, D. A., and Cheek, D. B.: Muscle electrolyte patterns during growth. In: D. B. Cheek: Human Growth, p. 260 (Lea \& Febiger, Philadelphia, 1968).

11. Evanson, J. M., and Stanbury, S. W.: Congenital chloridorrhoea or so-called congenital alkalosis with diarrhoea. Gut, 6: 29 (1965).

12. Fyhrquist, F., Soveri, P., Puutula, L., and Stenman, U.-H.: Radioimmunoassay of plasma renin activity. Clin. Chem., 22: 250 (1976).

13. Gamble, J. L., Fahey, K. R., Appleton, J., and MacLachlan, E.: Congenital alkalosis with diarrhea. J. Pediat., 26: 509 (1945).

14. Gorden, P., and Levitin, H.: Congenital alkalosis with diarrhea. A sequel to Darrow's original description. Ann. Intern. Med., 78: 876 (1973).

15. Hager-Malecka, B., Sychlowy, A., Kuźniarz, K., and Śmigla, K.: Congenital nephropathy and chronic diarrhoea with hypokalemic alkalosis. Z. Kinderheilk., 114: 31 (1973).

16. Harris, I., and Wilkinson, A. W.: Magnesium depletion in children. Lancet, i: 735 (1971).

17. Holmberg, C., Perheentupa, J., and Launiala, K.: Colonic electrolyte transport in health and in congenital chloride diarrhea. J. Clin. Invest., 56: 302 (1975).

18. Holmberg, C., Perheentupa, J., Launiala, K., and Hallman, N.: Congenital chloride diarrhoea: A clinical analysis of 21 Finnish patients. Arch. Dis. Childhood, 52: 255 (1977).

19. Holmberg, C., Perheentupa, J., and Pasternack, A.: The renal lesion in congenital chloride diarrhea. J. Pediat., 91: 738 (1977).

20. Jeune, M., Hermier, M., Harteman, E., Loras, B., Haour, F., Cotton, J. B., and Collombel, C.: Diarrhée chlorée congenitale avec alcalose métabolique. Pediatrie, 22: 663 (1967).

21. Kelsey, W. M.: Congenital alkalosis with diarrhea. Amer. J. Dis. Child., 88: 344 (1954).

22. Koushaupour, E.: Renal Physiology: Principles and Functions, p. 356 (W. B. Saunders Company, Philadelphia, 1976).

23. Launiala, K., Perheentupa, J., Pasternack, A., and Hallman, N.: Familial chloride diarrhea-chloride malabsorption. Modern Probl. Pädiat., 11: 137 (1968).

24. Lauras, B., Francois, B., Duc, H., Genoud, J., David, M., and Jeune, M.: Contribution a l'étude de la diarrhée chlorée congenitale. Arch. Franç. Pédiat., 30: 491 (1973).

25. Lifshitz, F., Harrison, H. C., Bull, E. C., and Harrison, H. E.: Citrate metabolism and the mechanism of renal calcification induced by magnesium depletion. Metabolism, 16: 345 (1967).

26. Lim, P., Jacob, E., Dong, S., and Khoo, O. T.: Values for tissue magnesium as a guide in detecting magnesium deficiency. J. Clin. Pathol., 22: 417 (1969).

27. Norio, R., Perheentupa, J., Launiala, K., and Hallman, N.: Congenital chloride diarrhea, an autosomal recessive disease. Genetic study of 14 Finnish and 12 other families. Clin. Genet., 2: 182 (1971).

28. Pasternack, A., and Perheentupa, J.: Hypertensive angiopathy in familial chloride diarrhea. Lancet, ii: 1047 (1966).

29. Pasternack, A., Perheentupa, J., Launiala, K., and Hallman, N.: Kidney biopsy findings in familial chloride diarrhea. Acta Endocrinol., 55: 1 (1967).

30. Pearson, A. J. G., Sladen, G. E., Edmonds, C. J., Tavill, A. S., Wills, M. R., and McIntyre, N.: The pathophysiology of congenital chloridorrhoea. Quart. J. Med., 42: 453 (1973).

31. Perheentupa, J., Eklund, J., and Hallman, N.: Chronic diarrhea and alkalosis. Pediatrics, 35: 516 (1965a).

32. Richards, P.: Clinical investigation of the effects of adrenal corticosteroid excess on the colon. Lancet, $i: 437$ (1969).

33. Seldin, D. W.; and Rector, F. C., Jr.: The generation and maintenance of metabolic alkalosis. Kidney Int., 1: 306 (1972).

34. Tauxe, W. N., and Orvis, A. L.: Nuclear medicine procedures in the clinical laboratory. In: J. Davidsohn and J. Henry: Clinical Diagnosis by Laboratory Methods, p. 474 (W. B. Saunders Company, Philadelphia, 1974).

35. Thoren, L.: Magnesium deficiency in gastrointestinal fluid loss. Acta Chir. Scand. Suppl. 306 (1963).

36. Turnberg, L. A.: Abnormalities in intestinal electrolyte transport in congenital chloridorrhoea. Gut, 12: 544 (1971).

37. Veall, N., and Wetter, H.: Radioisotope Techniques in Clinical Research and Diagnosis, p. 194 (Butterworth \& Co.; London, 1958).

38. Zettner, A., and Seligson, D.: Application of atomic absorption spectrophotometry in the determination of Ca in serum. Clin. Chem., 10: 869 (1964).

39. Dr. E. Häsänen from the Technical Research Centre of Finland, 02150 Otaniemi, Finland, did the neutron activation analysis for $\mathrm{Mg}^{++}$. His contribution is gratefully acknowledged.

40. Informed consent was always obtained from the parents before any investigations were carried out.

41. This study was supported by Grants from the Foundation for Pediatric Research, Helsinki, Finland.

42. Requests for reprints should be addressed to: C. Holmberg, M.D., Children's Hospital, University of Helsinki, SF-00290 Helsinki 29 (Finland).

43. Received for publication January $24,1977$.

44. Accepted for publication May 25, 1977. 